\title{
The Role of MET in Melanoma and Melanocytic Lesions
}

\author{
Yan Zhou, ${ }^{* \dagger}$ Kyu Young Song, ${ }^{* \dagger}$ and Alessio Giubellino ${ }^{* \dagger}$
}

From the Department of Laboratory Medicine and Pathology, ${ }^{*}$ and the Masonic Cancer Center ${ }^{\dagger}$ University of Minnesota, Minneapolis, Minnesota

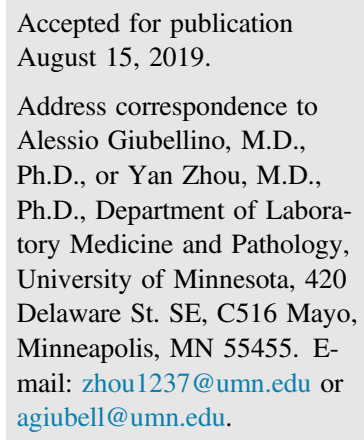

\begin{abstract}
Melanoma is the leading cause of death due to cutaneous malignancy and its incidence is on the rise. Several signaling pathways, including receptor tyrosine kinases, have been recognized to have an etiopathogenetic role in the development and progression of precursor melanocytic lesions and malignant melanoma. Among those, the hepatocyte growth factor/MET (HGF/MET) axis is emerging as a critical player not only in the tumor itself but also in the immune microenvironment in which the tumor grows and advances in its development. Moreover, the activation of this pathway has emerged as a paradigm of tumor resistance to modern targeted therapies, and the assessment of its expression in patients' samples may be a valuable biomarker of tumor progression and response to targeted therapy. Here we summarize our current understanding of this important receptor tyrosine kinase in normal melanocyte proliferation/motility, in tumor progression and metastasis, its genetic alterations in certain subtype of melanocytic lesions, and how its pathway has been explored for the development of selective inhibitors. (Am J Pathol 2019, 189: 2138-2148; https://doi.org/10.1016/j.ajpath.2019.08.002)
\end{abstract}

Melanoma is the most common lethal cancer among all skin malignancies, with a high propensity for metastasis. ${ }^{1}$ The 5 -year survival rate drops from about $98 \%$ in patients with early, localized disease to only $20 \%$ in those with metastatic melanoma. ${ }^{1}$ The estimated 5-year overall survival is $34 \%$ even in the era of immunotherapy such as the PD-1 inhibitor pembrolizumab. The annual incidence of malignant melanoma has increased by approximately $50 \%$ over the last decade. ${ }^{1,2}$

A variety of pathogenic mutations are associated with the initiation, progression, and metastasis of melanoma. Of these, the BRAFV600E mutation has been found in approximately half of malignant melanomas and tend to be more frequent in low-cumulative sun-induced damage melanomas. ${ }^{3,4}$ On the other hand, NRAS, NFI, and other $B R A F$ mutations are more frequently present in high-chronic sun-induced damage melanomas. ${ }^{4,5}$ Therapies targeting these mutations and relevant pathways have led to improved patient survival. However, the treatment of locally advanced or metastatic melanomas often requires systemic or combination approaches, including immunotherapy (the checkpoint inhibitors anti-programmed cell death protein 1 , anti- programmed cell death protein ligand 1 , or cytotoxic $\mathrm{T}$ lymphocyte-associated antigen 4 antibodies), targeted therapy [BRAF and/or mitogen-activated protein kinase kinase (MEK) inhibitors], and chemotherapy. ${ }^{6,7}$ The absolute survival rate remains quite low. ${ }^{8}$ Furthermore, immunotherapy and targeted therapy are often limited by high rates of resistance. ${ }^{9,10}$ Therefore, a better understanding of the molecular events involved in the progression and therapeutic resistance of melanoma is necessary.

Increasing attention has been drawn to the critical role of the hepatocyte growth factor (HGF)/MET pathway in melanoma development, progression, and therapeutic resistance. ${ }^{10,11}$ MET receptor, also known as HGF receptor , is expressed in the epithelial cells of many tissues, including skin, and the tumorigenic effect of the HGF/MET pathway has long been observed in malignancies of various organs. Therapies targeted toward this pathway have yielded improved clinical outcomes, especially in renal cell and lung carcinomas. ${ }^{12,13}$ Therefore, the observation of MET activation in melanoma may open up a new possibility of aid in

Supported by start-up funds from the Department of Laboratory Medicine and Pathology/Masonic Cancer Center, University of Minnesota (A.G.).

Disclosures: None declared. 
melanoma treatment. MET signaling aberrations have been found in melanomas at both sun-exposed and sun-shielded sites. Commonly found MET alterations include MET amplifications in desmoplastic melanoma, a high-chronic sun-induced damage melanoma, and MET rearrangements in Spitz melanoma as well as in its benign/intermediate precursor lesions. ${ }^{4}$ In the most recent large-scale wholegenome sequencing analysis of melanoma, which included 183 patient samples of cutaneous, mucosal, and acral subtypes, frequent $M E T$ aberrations were demonstrated, with 24\% gene amplifications, 9\% single-nucleotide variations/ deletions, and $1 \%$ structural variants. ${ }^{14}$ Therapies targeting the HGF/MET pathway have shown promising results in inhibiting melanoma growth and metastasis in preclinical studies. However, translations of MET inhibitors into clinical studies as single-therapy agents in melanoma, as in other cancers, have been largely unfruitful, possibly due to the complex crosstalk of the HGF/MET pathway with other oncogenic pathways. Recent ongoing efforts include the investigation of synergistic therapeutic effects of combination therapies involving MET inhibitors, and mechanistic studies of MET targeting to overcome therapeutic resistance. These studies promise to better define the roles of this pathway in melanoma and other malignancies and to more precisely guide clinical applications of its targeted therapy.

\section{MET Structure, HGF/MET Signaling, and Biological Functions}

The proto-oncogene MET on the 7q31 locus encodes MET, alias HGF receptor. ${ }^{15}$ HGF, a pleiotropic heparin-binding protein, binds to MET and elicits multiple biological activities such as mitogenic, motogenic, and morphogenic responses in various cell types, including melanocytes. ${ }^{16}$ HGF is produced as an inactive single-chain precursor that is processed to yield an active heterodimer of one $\alpha$ and one $\beta$ chain linked by a disulfide bond. ${ }^{17}$ MET is a transmembrane receptor composed of a glycosylated, extracellular $\alpha$ subunit and a transmembrane $\beta$ subunit. ${ }^{18}$ The $\alpha$ and the first 212 residues of the $\beta$ subunit serve as the extracellular binding site for HGF. ${ }^{19}$ The intracellular portion of the $\beta$ subunit contains three major domains: the juxtamembrane domain, the kinase domain, and the C-terminal docking site. ${ }^{16}$ Upon ligand binding, two tyrosine residues in the kinase domain, Y1234 and Y1235, are phosphorylated. Phosphorylation of two critical tyrosine residues, Y1349 and Y1356, within the C-terminal docking site recruits multiple intracellular molecules, including GRB2-associated-binding protein 1 (GAB1), growth factor receptor-bound protein 2 (GRB2), phosphatidylinositol 3 kinase (PI3K), phospholipase $\mathrm{C} \gamma$, Src, and Shc, via binding to a Src homology 2 domain or other recognition motifs. ${ }^{11,16}$ Consequently, multiple signaling pathways controlling cell survival, cell cycle progression, motility, and migration, including the PI3K/Akt, Ras/mitogen-activated protein kinase (MAPK), Rac1/cell division control protein 42 pathways, are activated (Figure 1). ${ }^{16}$

Under normal physiologic conditions, HGF produced by cells of mesenchymal origin acts in a paracrine manner to stimulate MET during embryonic development and throughout adulthood. ${ }^{16}$

\section{Role of MET and HGF in Melanocytes}

Normal human melanocytes do not secrete HGF but are receptive to HGF through the expression of MET. ${ }^{20}$ HGF functions as a mitogen, stimulating melanocyte proliferation, in synergy with basic fibroblast growth factor and mast cell growth factor. ${ }^{21}$ HGF/MET signaling also promotes melanocyte motility and maintains high levels of tyrosinase activity and melanin content. ${ }^{20,21}$ Ubiquitous overexpression of HGF in transgenic mice leads to hyperpigmentation in neonatal and adult skin and hyperproliferation of melanocytes in ectopic tissues. ${ }^{22}$ In addition, the up-regulation of MET expression via melanocyte-inducing transcription factor has been found to protect melanocytes from apoptosis. ${ }^{23}$ Under certain insults such as UV radiation, melanocyte-inducing transcription factor could directly bind to the MET promoter in response to the increased level of $\alpha$-melanocyte-stimulating hormone, ${ }^{23}$ further emphasizing the complexity of the interplay of different pathways.

Other studies have also revealed the regulatory roles of HGF/MET signaling in the development of melanocytes from neural crest. ${ }^{24}$ HGF promotes melanoblast survival and differentiation into pigmented melanocytes in vitro. Both in vitro and in vivo studies in mouse transgenic embryos have shown that the HGF/MET signaling can influence the initial development of neural crest-derived melanocytes. ${ }^{24}$ These studies not only offer a window on the role of this signaling pathway on physiologic melanocyte functions, but also highlight our incomplete understating and the need for additional studies.

\section{Role of RTKs in Melanoma and Melanocytic Lesions}

In malignancies, the HGF/MET pathway is aberrantly activated through several mechanisms, including paracrine signaling, activating mutations, overexpression, or autocrine loop formation. ${ }^{25}$ Abnormalities in receptor tyrosine kinase (RTK) expression have been demonstrated to contribute to melanoma development and progression. ${ }^{26}$ In transgenic mice, Ret overexpression or MET activation could lead to melanoma development. ${ }^{27}$ With advancement in technologies such as whole-genome sequencing, multiple forms of RTK aberrations have been discovered in melanoma cell lines and patient-derived samples. ${ }^{1,14}$ More than 20 RTK families, including epidermal growth factor receptor, extracellular region binding proteins 2 and 4, Kit, fibroblast growth factor receptor, MET, and platelet-derived growth factor receptor, are involved in melanoma tumorigenesis. ${ }^{14}$ RTK alterations 


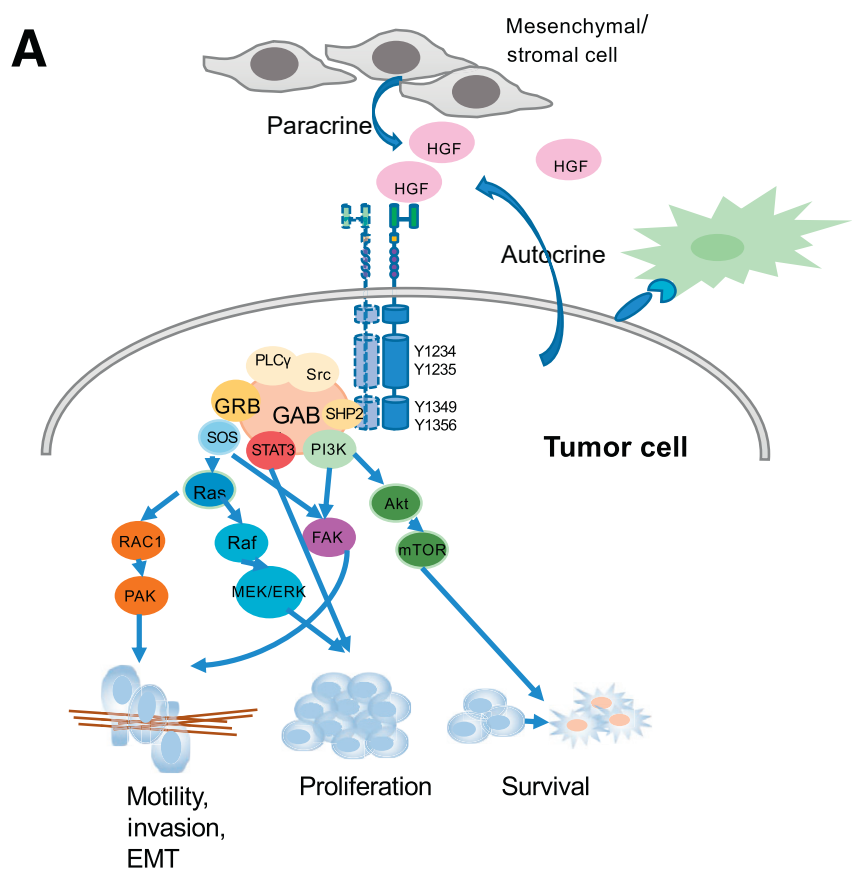

B

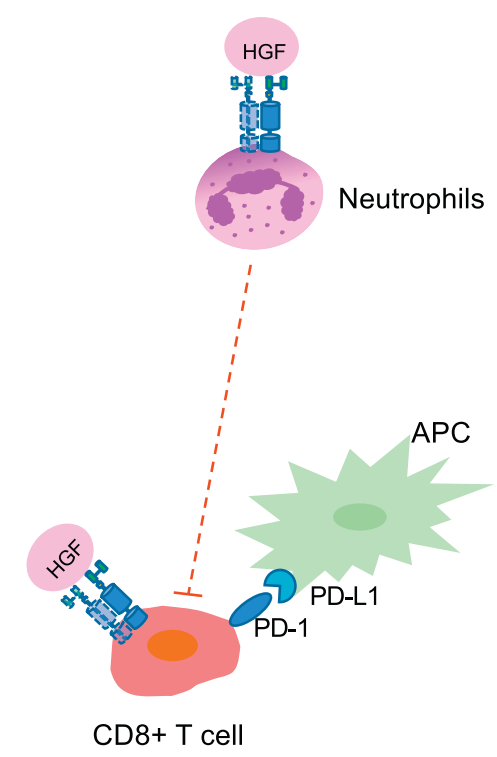

Figure 1 Summary of hepatocyte growth factor (HGF)/MET signaling and functions in tumor cells and microenvironment. A: HGF-induced activation of MET signaling cascade by either paracrine or autocrine manner. Phosphorylation of critical tyrosine residues triggers the recruitment of multiple effector molecules inside tumor cells, thus activating several downstream signaling pathways responsible for cell migration, proliferation, and survival. B: Endogenous HGF/MET axis can also be activated in neutrophils and cytotoxic $T$ cells in the tumor microenvironment. MET-dependent neutrophils may also indirectly affect the functions of T cells. APC, adenomatous polyposis coli; EMT, epithelial-mesenchymal transition; FAK, focal adhesion kinase; GAB, GRB2-associated-binding protein; GRB, growth factor receptor-bound protein; MEK, marker extraction kernel; $\mathrm{mTOR}$, mammalian target of rapamycin; PAK, p21-activated kinase; PD-L, programmed cell death protein ligand; PI3K, phosphatidylinositol 3-kinase; PLC, phospholipase C; SHP, small heterodimer partner; SLUG, human embryonic protein SNAI 2; Snai1, zinc finger protein SNA 1; SOS, son of sevenless protein; Twist, Twist family bHLH transcription factor. are frequently identified in cutaneous, acral, and mucosal melanomas, and may represent promising therapeutic targets.

In a subset of melanocytic neoplasms, recurrent rearrangements of kinases, have been described as a mechanism of oncogenic activation. ${ }^{28,29}$ The resulting chimeric proteins are constitutively active, stimulating oncogenic signaling pathways. In particular, gene rearrangements of $M E T$ resulting in in-frame MET kinase fusions are found in Spitz tumors and Spitzoid melanomas. ${ }^{30}$ MET fusions tend to occur in younger patients (with an average age of onset of 20 years), and are present across benign, atypical, to malignant lesions, suggesting early occurrence of the MET fusions during tumor progression. ${ }^{30}$ Common mutations in melanomas involving $N R A S, N F 1$, or BRAF are usually not present in Spitzoid neoplasms. However, some of them can become aggressive and metastasize. These lesions may require systemic therapy, but targeted therapeutic options for these melanocytic lesions do not currently exist. Since MET fusions occur in a subset of Spitzoid melanomas in a mutually exclusive pattern with activating mutations in known melanoma oncogenes, they may represent a unique therapeutic target in those lesions. ${ }^{29,30}$ Additional functional studies in mouse models and larger cohorts of patients with specific mutations or other genetic alterations will be required to evaluate the effects of each of these genetic alterations in melanoma, and to further develop tailored therapeutic strategies.

\section{Role of MET and HGF in Primary Melanoma}

Multiple mechanisms that confer oncogenic potential to HGF and MET in a wide variety of human cancers have been described, including autocrine or paracrine loop formation, MET-activating mutations, structural variants, and gene amplification. ${ }^{25}$ For example, a study showed that the HGF/MET autocrine loop stimulated the aberrant growth of melanocytes with endogenous MET overexpression and drove tumorigenesis in a transgenic mouse model. ${ }^{31}$ Several other studies have also shown that some melanomas in humans can express both MET and HGF, in contrast to normal melanocytes, which rarely produce HGF, further confirming the formation of an autocrine loop in melanoma development. ${ }^{5,32-34}$

Various MET mutations have been identified in melanoma. ${ }^{35}$ Among these, activating mutations in the MET kinase domain are most closely associated with its oncogenic capacity. ${ }^{25,36,37}$ Mutations within the MET juxtamembrane domain also have a role in tumorigenesis, cell motility, and migration. In lung cancer (eg, juxtamembrane), domain mutations result in alternative splicing of MET and production of more stable MET proteins. ${ }^{7,9,38}$ New missense MET mutations in the juxtamembrane domain, contributing to melanoma growth and progression, have been identified in a cell line (N948S) and tumor tissue (R988C). ${ }^{31}$ Other studies have questioned the association of MET mutations with adverse prognosis in malignant melanoma. ${ }^{6,16}$ 
The association of MET pathway activation with other well-known melanoma driver genes has also been investigated. ${ }^{10,14,39}$ In primary melanoma-derived cells in humans, Chattopadhyay et $\mathrm{al}^{39}$ observed a higher level of phosphorylation of MET (which leads to more robust pathway activation in response to HGF) in NRAS-mutated tumors when compared to $B R A F$-mutated tumors. ${ }^{10}$ Concurrently, pharmacologic inhibition of MET resulted in more potent inhibition of melanoma cell proliferation and migration in NRAS-mutated tumors compared to $B R A F$ mutated tumors. However, in a recent whole-genome analysis of various subtypes of melanoma, MET copy number amplification appeared to be associated with amplification of $B R A F$ hotspot mutations, possibly due to the proximity of the $M E T$ and $B R A F$ genes on chromosome $7 .{ }^{14}$ Such an association was not observed between MET and NRAS. Further and better understanding of the association between types and prevalence of $M E T$ alterations and other common oncogene mutations in melanoma may be needed, in light of the potential benefit of combined targeting for optimal synergistic effects in selected subtypes of melanomas.

\section{Role of MET and HGF in Melanoma Metastasis}

Melanomas are highly metastatic tumors. As aforementioned, HGF/MET signaling promotes several critical steps in cancer cell invasion and metastasis, such as cell scattering, migration, extracellular matrix degradation, and angiogenesis. ${ }^{27}$ Mechanistically, cytoplasmic signaling cascades downstream of MET, including PI3K/Akt and Rac1-cell division control protein 42 pathways, may induce cell cytoskeletal changes and affect cell surface integrin and cadherin expressions, thus controlling cell migration and adhesion processes. ${ }^{40}$

The role of the HGF/MET pathway in metastatic melanoma has been studied in the B16 melanoma cell model, where MET activation was required for metastasis and colonization of melanoma cells in liver, possibly by inducing cell motility and invasion in response to HGF in a paracrine manner. ${ }^{41}$ Moreover, MET-induced melanoma cell migration could be completely inhibited by a selective MET inhibitor, indicating the necessity of its pathway in this process. ${ }^{42,43}$ The efficacy of certain MET inhibitors (such as crizotinib) in inhibiting metastasis in preclinical mouse models and patients is currently being evaluated. ${ }^{44}$

\section{Role of MET and HGF in Epithelial-Mesenchymal Transition}

Epithelial-mesenchymal transition (EMT) is an essential process contributing to the progression of epithelial cancers from localized disease to invasion and metastasis. Experimental evidence demonstrates the critical roles of phenotype switching (analogous to EMT) in both melanocyte differentiation and melanoma progression to metastatic disease. ${ }^{45,46}$ As in epithelial cancers, the EMT-like phenotype switching in melanoma is associated with the loss of E-cadherin and the gains of $\mathrm{N}$-cadherin, osteopontin, and osteonectin. ${ }^{46}$ However, with a neural crest derivation, melanocytes and melanoma cells differ from both epithelial and mesenchymal cells phenotypically. A recent review has described the similarities and differences in the expressions and regulations of the common EMT-transcriptional factors between epithelial cancers and melanoma. ${ }^{45}$ For example, zinc finger protein SNA 1 and 2 (SNAIL1 and SNAI2), human embryonic protein SNAI 2 (SLUG), zinc finger E box-binding homeobox 1 and 2 (ZEB1 and ZEB2), and Twist family bHLH transcription factor (Twist) are all considered as important repressors of E-cadherin in epithelial carcinomas. However, an opposite role of ZEB2, that is, the promotion of differentiation and preservation of E-cadherin expression, was found in melanoma. ${ }^{47}$ Once more, these discrepancies outline our incomplete knowledge and the need for additional studies.

Several studies have demonstrated that the activation of the HGF/MET pathway promotes EMT through the regulation of multiple known repressors of E-cadherin in melanomas (Figure 2). ${ }^{33,48,49}$ In one study, autocrine activation (by adenovirus-induced HGF expression) of MET leads to constitutive activation of MAPK and PI3K and downregulation of E-cadherin and desmoglein 1 in both normal melanocytes and melanoma cell lines. ${ }^{33}$ After exposure to exogenous human recombinant HGF, several melanoma cell lines express up-regulated amounts of SNAIL1, Twist, and human embryonic protein SNAI2 at various time points, mediating the switch from E-cadherin to $\mathrm{N}$-cadherin. ${ }^{48}$ Another study showed that downstream activation of the MAPK/early growth response 1 (Egr-1) pathway is required in HGF/MET-induced SNAIL1 up-regulation. ${ }^{49}$ HGF-induced activation of the MAPK/Egr-1 pathway also exhibits several other functions, including promoting fibronectin matrix synthesis, which mediates melanoma cell migration. ${ }^{50}$

In addition, CD44 isoforms have been found to be critical regulators of EMT. ${ }^{51}$ For example, Recio and Merlino ${ }^{52}$ found that in a murine melanoma cell line, transcriptional Egr-1 activation up-regulates CD44v6 expression, facilitating the binding and presentation of $\mathrm{Hgf}$ to its receptor.

Together, the findings from these studies unveil the mounting evidence of the role of the HGF/MET pathway in EMT in melanoma, and further confirm the use of MET inhibitors as a viable therapeutic avenue to preventing metastatic disease.

\section{Role of MET and HGF in Immunomodulation in Melanoma}

The HGF/MET axis is also involved in the modulation of innate and adaptive immune responses and tissue repair. ${ }^{53}$ Immune cells in the tumor microenvironment exert both antitumor and protumor effects in several cancers, including 

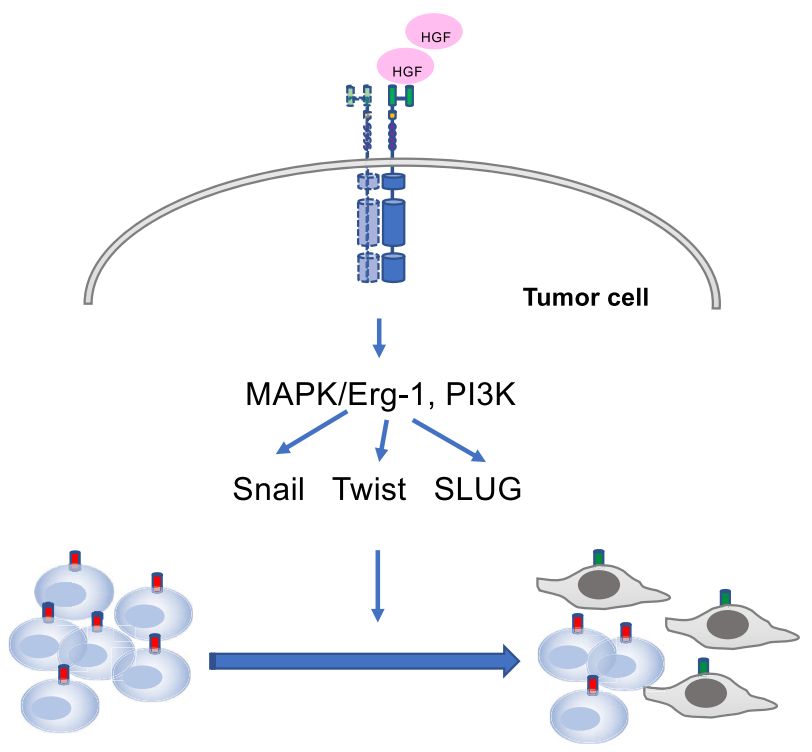

\section{E-cadherin N-cadherin}

Figure 2 Hepatocyte growth factor (HGF)/MET pathway activation promotes epithelial-mesenchymal transition through up-regulation of multiple E-cadherin repressors and mediating switch from E-cadherin to $\mathrm{N}$ cadherin. Erg, erythroblast transformation-specific transcription factor; MAPK, mitogen-activated protein kinase; PI3K, phosphatidylinositol 3kinase; SLUG, human embryonic protein SNAI2.

melanoma. In this setting, the role in immunomodulation by the HGF/MET pathway in cancer deserves further investigation and may provide valuable therapeutic implications.

Recently HGF/MET signaling has been demonstrated to be required for neutrophil migration to the tumor microenvironment in melanoma. ${ }^{54}$ These antitumor neutrophils exert cytotoxic effects on tumor cells via the production of inducible nitric oxide synthase and nitric oxide (Figure 3). MET deletion in neutrophils, on the other hand, promote cancer growth and metastasis by reducing antitumoral neutrophilic recruitment. These mechanisms may offer in part an explanation for some limited results of selective MET inhibitors in clinical trials.

Glodde et $\mathrm{al}^{55}$ also found that HGF/MET signaling mediated the recruitment of reactive neutrophils from bone marrow to tumor and lymph nodes, following immunotherapies such as adoptive T-cell transfer or checkpoint blockade. However, these MET-expressing neutrophils impaired therapeutic T-cell proliferation, thus limiting the efficacy of immunotherapies (Figure 3). Concurrent inhibition of MET successfully potentiated the efficacy of cancer immunotherapy in melanoma-bearing mouse models. Interestingly, patient data mirrored the results in mouse models, showing an increase in serum HGF and blood neutrophil counts in anti-programmed cell death protein 1 therapy nonresponders with advanced melanoma.

A subset of endogenous MET-positive cytotoxic T cells has also been found in melanoma patients, and HGF directly limited the tumor-killing functions of these $\mathrm{Met}^{+} \mathrm{CD} 8^{+}$ tumor-infiltrating lymphocytes in a metastatic melanoma mouse model. ${ }^{56}$ The role of HGF/MET as an immunosuppressive signaling pathway is also put in evidence through the induction of tolerogenic DCs and Langerhans cells, as seen in experimental models of graft-versus-host disease and autoimmune encephalomyelitis. ${ }^{53}$ Finally, in carcinomas, MET signaling-induced phosphorylation of $\alpha_{6 \beta 4}$-integrin possibly contributes to the migration of DCs and Langerhans cells. ${ }^{57}$

Although our current knowledge of the role of the HGF/ MET signaling axis is piecemeal at best, overall these pathways appear to be mostly immunosuppressive in cancer immune responses, although additional studies will be necessary to fully understand the therapeutic implications at a time of excitement for the promise of cancer immunotherapy.

\section{Role of MET and HGF in Therapeutic Resistance in Melanoma}

The treatment of malignant melanoma has been more recently revolutionized by the introduction of small-molecule targeted therapies and immune checkpoint inhibitors. In particular, BRaf inhibitors (eg, vemurafenib, the first approved targeted therapy for $B R A F V 600 E$ metastatic melanoma) have achieved significant improvement in PFS and OS, with a response rate of $50 \%$ to $60 \%$. ${ }^{6,58}$ The combination of BRAF and MEK inhibitors has further improved the response rate to $70 \% .^{59}$ However, almost all patients eventually develop resistance after BRAF or BRAF-MEK combined inhibition. ${ }^{58}$

Resistance to BRAF and/or MEK inhibitors may be acquired via a broad spectrum of both genomic and nongenomic mechanisms. ${ }^{10,60}$ Among these, growth factor-mediated reactivation of MAPK and/or PI3K pathway via RTKs has been found to be an important resistance mechanism, ${ }^{61}$ and specifically, HGF/MET pathway activation has been demonstrated recently to elicit both innate and acquired resistance to BRAF inhibitors.

In a recent preclinical study using 12 BRAF inhibitor-resistant patient-derived xenograft models, MET amplification was observed at a higher frequency, and it tended to coexist with $B R A F$ hotspot mutation. ${ }^{62}$ Moreover, triple combination of BRAF, MEK, and MET inhibitors (capmatinib, encorafenib, binimetinib) leads to complete and sustained tumor regression in vivo. On further analysis, both therapynaive lesions and post-therapy metastatic samples were found to be MET positive, suggesting that $M E T$ amplification is a preexisting event contributing to the intrinsic resistance to BRAF inhibitors. In addition, increased HGF secretion in the tumor microenvironment represents another mechanism to induce innate resistance to BRAF inhibitors. ${ }^{63}$

The mechanisms of MET activation in acquired resistance to BRAF/MEK inhibitors have also been studied. ${ }^{10,60,64}$ Caenepeel et $\mathrm{al}^{10}$ found that MAPK pathway inhibition after BRAF inhibitor treatment induced rapid increases in MET and growth factor receptor-bound protein 2-associated binder 1 expression; a similar increase in MET also occurred after 


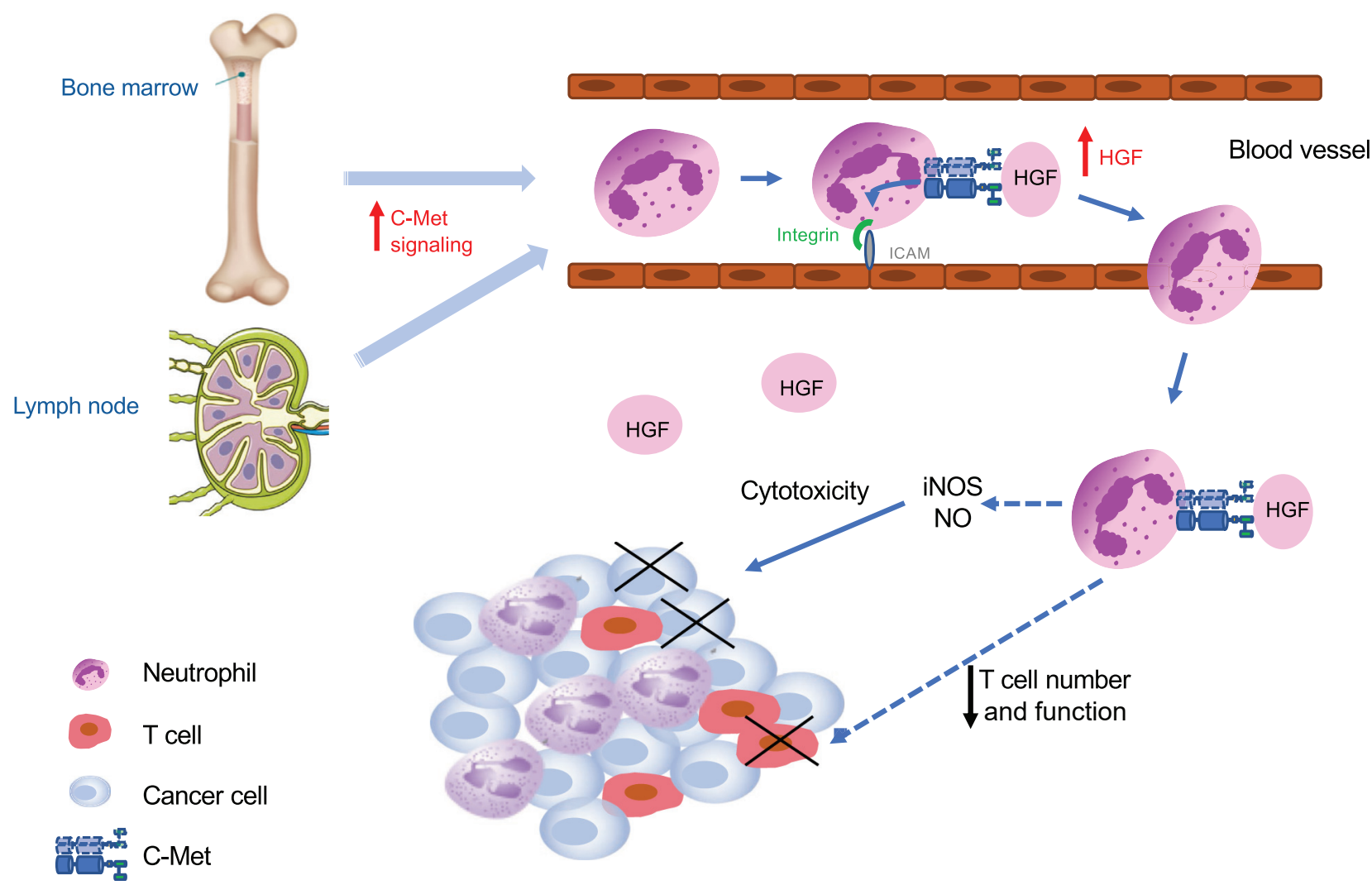

Figure 3 Roles of MET signaling in immunomodulation of melanoma microenvironment. MET activation recruits neutrophils to the tumor microenvironment, which may lead to direct cytotoxicity to melanoma cells or may inhibit functions of tumor infiltrating lymphocytes. HGF, hepatocyte growth factor; ICAM, intercellular adhesion molecule; iNOS, inducible nitric oxide synthase; NO, nitric oxide.

MEK pathway inhibition in NRAS-mutated melanoma cell lines. Furthermore, in vivo experiments have suggested that tumor-derived HGF may be required to rescue melanoma cells from BRAF/MEK inhibitors. An association between MET levels and strength of HGF rescue after vemurafenib treatment has been observed, indicating the potential use of MET levels as a biomarker to identify patients suitable for MET inhibitor combination therapy. ${ }^{10}$ Another study identified hypoxiadriven up-regulation of HGF/MET signaling as a major mechanism of resistance to several BRAF inhibitors in melanoma patients and mouse xenografts. ${ }^{64} \mathrm{~A}$ recent transcriptomic-methylomic analysis revealed recurrently increased MET mRNA expression in resistant tumors, possibly due to differential $\mathrm{CpG}$ cluster methylation. ${ }^{30,60}$ Further investigations of upstream and downstream components involved in the mechanisms of resistance to BRAF/ MEK inhibitors are of paramount importance to understand how to overcome therapeutic resistance in melanoma and ultimately understand the therapeutic potential of MET inhibitors in this setting.

\section{Targeting the HGF/MET Signaling Pathway for the Treatment of Melanoma}

Several HGF/MET pathway inhibitors have been developed in the last 2 decades. Promising results have been reported, especially in papillary renal cell carcinoma and non-small cell lung carcinoma (NSCLC). ${ }^{12,13}$ Table 1 focuses on trials that have evaluated these inhibitors in melanoma. Pharmacologic MET inhibition has been tested in melanoma patients both as single agents or in combination with other anticancer therapies. Most recently combinations with immunotherapy or BRAF/MEK inhibitors have been tested to improve efficacy or to overcome resistance. Analyses of $M E T$ alteration in several trials have guided the use of these inhibitors.

Capmatinib (INC280) is an oral selective MET inhibitor tested in MET fusion-positive patients with wild-type $B R A F / N R A S$ metastatic melanomas (NCT02587650), or in patients with advanced $B R A F$-mutated melanoma after progression following standard treatments (NCT01820364, NCT02159066). Genetic analysis of tumor biopsy samples has been used to stratify patients into appropriate targeted therapy groups. One of these Phase II trials (NCT01820364) was terminated early for scientific and business factors, not for safety concerns, and given the small cohort of patients, the results were insufficient for a definitive interpretation. The other trial (NCT02159066) is still ongoing, so no results are available at the moment.

Crizotinib (PF-02341066) is a potent inhibitor of MET, anaplastic lymphoma kinase, and reactive oxygen species $1{ }^{44}$ It has received US Food and Drug Administration 
Table 1 MET Inhibitors for Malignant Melanoma in Clinical Trials

\begin{tabular}{|c|c|c|c|c|c|c|c|}
\hline Drug & Design & Phase & Start date & Status & Patient population & $\begin{array}{l}\text { Combinations } \\
\text { /comparisons }\end{array}$ & Clinical trial* \\
\hline \multirow[t]{2}{*}{ Crizotinib } & Efficacy/toxicity & II & $\begin{array}{l}\text { March } \\
2015\end{array}$ & $\begin{array}{l}\text { Active, } \\
\text { not } \\
\text { recruiting }\end{array}$ & $\begin{array}{l}\text { Uveal melanoma } \\
\text { with high risk } \\
\text { of recurrence } \\
\text { after definitive } \\
\text { therapy with } \\
\text { surgery or } \\
\text { radiation }\end{array}$ & None & NCT02223819 \\
\hline & $\begin{array}{l}\text { Efficacy/genetic } \\
\text { aberrations }\end{array}$ & IV & $\begin{array}{c}\text { February } \\
2019\end{array}$ & $\begin{array}{l}\text { Active, } \\
\text { not } \\
\text { recruiting }\end{array}$ & $\begin{array}{l}\text { Unresectable Stage } \\
\text { III or Stage IV } \\
\text { metastatic } \\
\text { melanoma with } \\
\text { or without } \\
\text { BRAF/NRAS } \\
\text { mutations }\end{array}$ & $\begin{array}{l}\text { Comparing to } \\
\text { standard therapy } \\
\text { /clinical trial; } \\
\text { matched targeted } \\
\text { therapy; trametinib } \\
\text { and/or } \\
\text { supportive care }\end{array}$ & NCT02645149 \\
\hline & $\begin{array}{l}\text { Efficacy/safety/ } \\
\text { tolerability/ } \\
\text { pharmacokinetics } \\
\text { /pharmacodynamics }\end{array}$ & II & $\begin{array}{r}\text { August } \\
2009\end{array}$ & Completed & $\begin{array}{l}\text { Advanced/recurrent/ } \\
\text { metastatic solid } \\
\text { tumors ( } 9 \text { types) } \\
\text { including melanoma }\end{array}$ & None & NCT00940225 \\
\hline & Efficacy/safety & II & $\begin{array}{l}\text { July } \\
2013\end{array}$ & $\begin{array}{l}\text { Completed } \\
\text { (no results } \\
\text { posted) }\end{array}$ & $\begin{array}{l}\text { Recurrent or Stage } \\
\text { III/IV uveal } \\
\text { melanoma }\end{array}$ & $\begin{array}{l}\text { Comparing to } \\
\text { temozolomide or } \\
\text { dacarbazine }\end{array}$ & NCT01835145 \\
\hline & Efficacy/safety & II & $\begin{array}{l}\text { July } \\
2014\end{array}$ & $\begin{array}{l}\text { Active, } \\
\text { not } \\
\text { recruiting }\end{array}$ & $\begin{array}{l}\text { Locally advanced or } \\
\text { metastatic BRAF } \\
\text { V600 melanoma }\end{array}$ & $\begin{array}{l}\text { LGX818 + MEK162 }+ \\
\text { either capmatinib or } \\
\text { LEE011 or BGJ398 or } \\
\text { BKM120 }\end{array}$ & NCT02159066 \\
\hline & Efficacy/safety & II & $\begin{array}{l}\text { March } \\
2013\end{array}$ & Terminated & $\begin{array}{l}\text { Advanced BRAF mutant } \\
\text { melanoma }\end{array}$ & $\begin{array}{l}\text { LGX818 + either } \\
\text { capmatinib or } \\
\text { MEK162 or LEE011 } \\
\text { or BGJ398 or BKM120 }\end{array}$ & NCT01820364 \\
\hline & Efficacy/safety & II & $\begin{array}{l}\text { March } \\
2015\end{array}$ & Recruiting & $\begin{array}{l}\text { BRAF/NRAS wild-type } \\
\text { Stage III-IV melanoma }\end{array}$ & $\begin{array}{l}\text { Either capmatinib or } \\
\text { certinib or entrectinib } \\
\text { or regorafenib } \\
\text { (depending on the } \\
\text { fusion kinase status) }\end{array}$ & NCT02587650 \\
\hline
\end{tabular}

(table continues) 
Table 1 (continued)

\begin{tabular}{|c|c|c|c|c|c|c|c|}
\hline Drug & Design & Phase & Start date & Status & Patient population & $\begin{array}{l}\text { Combinations } \\
\text { /comparisons }\end{array}$ & Clinical trial* \\
\hline $\begin{array}{l}\text { Tivantinib } \\
\text { (ARQ197) }\end{array}$ & Safety/efficacy & I/II & $\begin{array}{r}\text { August } \\
2010\end{array}$ & $\begin{array}{l}\text { Active, } \\
\text { not } \\
\text { recruiting }\end{array}$ & $\begin{array}{l}\text { Various advanced solid } \\
\text { tumors including } \\
\text { melanoma, HCC, RCC, } \\
\text { NSCLC, breast cancer, } \\
\text { and ovarian cancer }\end{array}$ & $\begin{array}{l}\text { Monotherapy or in } \\
\text { combination with } \\
\text { other drug(s) }\end{array}$ & NCT01178411 \\
\hline $\begin{array}{l}\text { Met RNA } \\
\text { CAR T cells }\end{array}$ & Safety/efficacy & Early I & $\begin{array}{l}\text { December } \\
2016\end{array}$ & Recruiting & $\begin{array}{l}\text { Advanced melanoma or } \\
\text { breast carcinoma }\end{array}$ & None & NCT03060356 \\
\hline
\end{tabular}

*Available at http://clinicaltrials.gov.

${ }^{\dagger}$ Has passed its completion date and status not been verified in more than 2 years.

CAR, chimeric antigen receptor; HCC, hepatocellular carcinoma; NSCLC, non-small cell lung cancer; RCC, renal cell carcinoma.

(FDA) approval for the treatment of patients with metastatic NSCLC who were anaplastic lymphoma kinase positive or reactive oxygen species 1 positive in 2011 and 2016, respectively (https://www.fda.gov/Drugs/InformationOn Drugs/ApprovedDrugs/ucm490391.htm, last accessed July 2, 2019). Moreover, in May 2018, the FDA granted crizotinib two breakthrough designations, one of which was for patients bearing previously treated metastatic NSCLC with MET exon 14 alterations (Pfizer, New York, NY). The inhibitory effects of crizotinib on MET were also observed in other cancers, including urothelial carcinoma, papillary renal cell carcinoma type 1 , and uveal melanoma. ${ }^{13,44}$ In uveal melanoma, crizotinib inhibited cell migration at a concentration sufficient for preventing phosphorylation of the MET receptor but not of ALK or reactive oxygen species 1. Moreover, in a metastatic mouse model of uveal melanoma, crizotinib strongly inhibited the development of metastasis of uveal melanoma. ${ }^{44}$ Its efficacy in prolonging relapse-free survival in patients with high-risk uveal melanoma has been under investigation in an ongoing Phase II clinical trial (NCT02223819).

Cabozantinib (XL184) is another broad-spectrum, smallmolecule kinase inhibitor targeting multiple proteins including MET, vascular endothelial growth factor receptor 2, Ret proto-oncogene, AXL receptor tyrosine kinase protein, Kit, and fms-like tyrosine kinase 3. It was FDA approved for the treatment of metastatic medullary thyroid cancer in 2012 and for the treatment of advanced renal cell carcinoma after failure from prior antiangiogenic therapy in 2016 (https://www.fda.gov/drugs/informationondrugs/ approveddrugs/ucm497483.htm, last accessed July 2, 2019). Due to its potent activity in suppressing tumor growth, angiogenesis, and metastasis in various solid tumors, cabozantinib has been under study for its efficacy in several human malignancies, such as breast, melanoma, and hepatocellular carcinomas; SCLC; NSCLC; and ovarian, pancreatic, and prostate cancers. ${ }^{12,65,66}$
Specifically, in a cohort of patients with metastatic melanoma (NCT00940225), the median progression-free survival with cabozantinib treatment was 5.7 months, longer than that in patients receiving placebo (3 months). However, the difference was not statistically significant, and further investigation on clinical efficacy may be warranted. That study not only covered patients with cutaneous/mucosal subtypes of melanoma (70\%), but also those with uveal melanoma (30\%). The median PFS in patients with uveal melanoma was 4.8 months, suggesting antitumor activity regardless of melanoma subtype. ${ }^{65}$

Patients with uveal melanoma are usually excluded from clinical trials in melanoma patients due to resistance to standard therapies, poor prognosis, and high risk for liver metastasis in uveal melanoma. ${ }^{65}$ However, MET represents a rational target for uveal melanoma; its up-regulation and subsequent pro-proliferation/metastasis effects may be associated with mutations in the GNAQ and GNA11 genes, which are present in $>80 \%$ of cases of uveal melanoma ${ }^{67}$ A Phase II trial was initiated to assess the efficacy of cabozantinib specifically in patients with recurrent or advanced uveal melanoma (NCT01835145); results are currently under review.

Tivantinib (ARQ 197) is a highly selective oral MET inhibitor that binds to the dephosphorylated MET kinase. Its safety and efficacy have been evaluated in several clinical trials in various advanced solid tumors including hepatocellular carcinoma, renal cell carcinoma, melanoma, NSCLC, breast, and ovarian cancers. The preliminary disease control rate $(\geq 8$ weeks) was $58 \%$ in all patients, $90 \%$ in renal cell carcinoma, $65 \%$ in hepatocellular carcinoma, and $63 \%$ in melanoma. ${ }^{68}$ However, tivantinib failed to improve overall survival over placebo in patients with MET-high advanced hepatocellular carcinoma previously treated with sorafenib in a Phase III clinical trial. ${ }^{69}$ Currently no definitive clinical data on melanoma patients in this trial are available.

Overall, these clinical studies suggest interest in investigating the role of MET inhibitors in treating melanoma, but 
the efficacy data are still limited. A better patient stratification based on molecular profile may likely aid in the development of these therapies.

\section{Conclusions}

Recent preclinical and clinical studies highlight the important roles of the HGF/MET signaling pathway in melanoma progression, metastasis, and therapeutic resistance. MET exerts these functions through downstream interactions with a multitude of other signaling pathways critical for proliferation, cell survival, and migration, and by acting on both cancer cells and tumor microenvironment. Targeted therapies inhibiting MET signaling have been under active investigation in patients with malignant melanoma, with promising but still limited efficacy data. Ongoing clinical studies suggest that the combination of HGF/MET inhibitors with immunotherapies or targeted therapies may represent an effective therapeutic approach for improving outcomes in melanoma patients. More research investigating the mechanisms contributing to therapy resistance and/or synergistic effect with other currently available therapies may accelerate the development and application of HGF/MET-targeted therapies in melanoma treatment.

\section{References}

1. Siegel RL, Miller KD, Jemal A: Cancer statistics, 2018. CA Cancer J Clin 2018, 68:7-30

2. Jemal A, Siegel R, Ward E, Murray T, Xu J, Smigal C, Thun MJ: Cancer statistics, 2006. CA Cancer J Clin 2006, 56:106-130

3. Davies H, Bignell GR, Cox C, Stephens P, Edkins S, Clegg S, et al: Mutations of the BRAF gene in human cancer. Nature 2002, 417: 949-954

4. Elder D, Lazar A, Barnhill B, Massi D, Bastian B, Mihm MJ, Cook M, Nagore E, de la Fouchardiere A, Scolyer R, Gerami P, Yun S: Melanocytic tumours: introduction. Edited by Elder D, Massi D, Scolyer R, Willemze R. In WHO Classification of Skin Tumours. ed 4; 2018. pp. 66-75

5. Shain AH, Bastian BC: From melanocytes to melanomas. Nat Rev Cancer 2016, 16:345-358

6. Chapman PB, Hauschild A, Robert C, Haanen JB, Ascierto P, Larkin J, Dummer R, Garbe C, Testori A, Maio M, Hogg D, Lorigan P, Lebbe C, Jouary T, Schadendorf D, Ribas A, O'Day SJ, Sosman JA, Kirkwood JM, Eggermont AM, Dreno B, Nolop K, Li J, Nelson B, Hou J, Lee RJ, Flaherty KT, McArthur GA, Group B-S: Improved survival with vemurafenib in melanoma with BRAF V600E mutation. N Engl J Med 2011, 364:2507-2516

7. Wolchok JD, Chiarion-Sileni V, Gonzalez R, Rutkowski P, Grob JJ, Cowey CL, Lao CD, Wagstaff J, Schadendorf D, Ferrucci PF, Smylie M, Dummer R, Hill A, Hogg D, Haanen J, Carlino MS, Bechter O, Maio M, Marquez-Rodas I, Guidoboni M, McArthur G, Lebbe C, Ascierto PA, Long GV, Cebon J, Sosman J, Postow MA, Callahan MK, Walker D, Rollin L, Bhore R, Hodi FS, Larkin J: Overall survival with combined nivolumab and ipilimumab in advanced melanoma. N Engl J Med 2017, 377:1345-1356

8. Hamid O, Robert C, Daud A, Hodi FS, Hwu WJ, Kefford R, Wolchok JD, Hersey P, Joseph R, Weber JS, Dronca R, Mitchell TC, Patnaik A, Zarour HM, Joshua AM, Zhao Q, Jensen E, Ahsan S, Ibrahim N, Ribas A: Five-year survival outcomes for patients with advanced melanoma treated with pembrolizumab in KEYNOTE-001. Ann Oncol 2019, 30:582-588

9. Hugo W, Zaretsky JM, Sun L, Song C, Moreno BH, Hu-Lieskovan S, Berent-Maoz B, Pang J, Chmielowski B, Cherry G, Seja E, Lomeli S, Kong X, Kelley MC, Sosman JA, Johnson DB, Ribas A, Lo RS: Genomic and transcriptomic features of response to anti-PD-1 therapy in metastatic melanoma. Cell 2016, 165:35-44

10. Caenepeel S, Cooke K, Wadsworth S, Huang G, Robert L, Moreno BH, Parisi G, Cajulis E, Kendall R, Beltran P, Ribas A, Coxon A, Hughes PE: MAPK pathway inhibition induces MET and GAB1 levels, priming BRAF mutant melanoma for rescue by hepatocyte growth factor. Oncotarget 2017, 8:17795-17809

11. Al-U'datt DG, Al-Husein BAA, Qasaimeh GR: A mini-review of cMet as a potential therapeutic target in melanoma. Biomed Pharmacother 2017, 88:194-202

12. De Silva DM, Roy A, Kato T, Cecchi F, Lee YH, Matsumoto K, Bottaro DP: Targeting the hepatocyte growth factor/Met pathway in cancer. Biochem Soc Trans 2017, 45:855-870

13. Schöffski P, Wozniak A, Escudier B, Rutkowski P, Anthoney A, Bauer S, Sufliarsky J, van Herpen C, Lindner LH, Grünwald V, Zakotnik B, Lerut E, Debiec-Rychter M, Marréaud S, Lia M, Raveloarivahy T, Collette S, Albiges L: Crizotinib achieves longlasting disease control in advanced papillary renal-cell carcinoma type 1 patients with MET mutations or amplification. EORTC 90101 CREATE trial. Eur J Cancer 2017, 87:147-163

14. Hayward NK, Wilmott JS, Waddell N, Johansson PA, Field MA, Nones K, et al: Whole-genome landscapes of major melanoma subtypes. Nature 2017, 545:175-180

15. Bottaro DP, Rubin JS, Faletto DL, Chan AM, Kmiecik TE, Vande Woude GF, Aaronson SA: Identification of the hepatocyte growth factor receptor as the c-met proto-oncogene product. Science 1991, 251:802-804

16. Birchmeier C, Birchmeier W, Gherardi E, Vande Woude GF: Met, metastasis, motility and more. Nat Rev Mol Cell Biol 2003, 4: 915-925

17. Nakamura T, Nishizawa T, Hagiya M, Seki T, Shimonishi M, Sugimura A, Tashiro K, Shimizu S: Molecular cloning and expression of human hepatocyte growth factor. Nature 1989, 342:440-443

18. Rodrigues GA, Naujokas MA, Park M: Alternative splicing generates isoforms of the met receptor tyrosine kinase which undergo differential processing. Mol Cell Biol 1991, 11:2962-2970

19. Gherardi E, Youles ME, Miguel RN, Blundell TL, Iamele L, Gough J, Bandyopadhyay A, Hartmann G, Butler PJ: Functional map and domain structure of MET, the product of the c-met protooncogene and receptor for hepatocyte growth factor/scatter factor. Proc Natl Acad Sci U S A 2003, 100:12039-12044

20. Saitoh K, Takahashi H, Sawada N, Parsons PG: Detection of the cmet proto-oncogene product in normal skin and tumours of melanocytic origin. J Pathol 1994, 174:191-199

21. Halaban R, Rubin JS, Funasaka Y, Cobb M, Boulton T, Faletto D, Rosen E, Chan A, Yoko K, White W: Met and hepatocyte growth factor/scatter factor signal transduction in normal melanocytes and melanoma cells. Oncogene 1992, 7:2195-2206

22. Takayama H, La Rochelle WJ, Anver M, Bockman DE, Merlino G: Scatter factor/hepatocyte growth factor as a regulator of skeletal muscle and neural crest development. Proc Natl Acad Sci U S A 1996, 93:5866-5871

23. Beuret L, Flori E, Denoyelle C, Bille K, Busca R, Picardo M, Bertolotto C, Ballotti R: Up-regulation of MET expression by alphamelanocyte-stimulating hormone and MITF allows hepatocyte growth factor to protect melanocytes and melanoma cells from apoptosis. J Biol Chem 2007, 282:14140-14147

24. Kos L, Aronzon A, Takayama H, Maina F, Ponzetto C, Merlino G, Pavan W: Hepatocyte growth factor/scatter factor-MET signaling in neural crest-derived melanocyte development. Pigment Cell Res 1999, 12:13-21

25. Lai AZ, Abella JV, Park M: Crosstalk in Met receptor oncogenesis. Trends Cell Biol 2009, 19:542-551 
26. Easty DJ, Gray SG, O’Byrne KJ, O'Donnell D, Bennett DC: Receptor tyrosine kinases and their activation in melanoma. Pigment Cell Melanoma Res 2011, 24:446-461

27. Otsuka T, Takayama H, Sharp R, Celli G, LaRochelle WJ, Bottaro DP, Ellmore N, Vieira W, Owens JW, Anver M, Merlino G: c-Met autocrine activation induces development of malignant melanoma and acquisition of the metastatic phenotype. Cancer Res 1998, $58: 5157-5167$

28. Wiesner T, He J, Yelensky R, Esteve-Puig R, Botton T, Yeh I, Lipson D, Otto G, Brennan K, Murali R, Garrido M, Miller VA, Ross JS, Berger MF, Sparatta A, Palmedo G, Cerroni L, Busam KJ, Kutzner H, Cronin MT, Stephens PJ, Bastian BC: Kinase fusions are frequent in Spitz tumours and spitzoid melanomas. Nat Commun 2014, 5:3116

29. Tetzlaff MT, Reuben A, Billings SD, Prieto VG, Curry JL: Toward a molecular-genetic classification of spitzoid neoplasms. Clin Lab Med 2017, 37:431-448

30. Yeh I, Botton T, Talevich E, Shain AH, Sparatta AJ, de la Fouchardiere A, Mully TW, North JP, Garrido MC, Gagnon A, Vemula SS, McCalmont TH, LeBoit PE, Bastian BC: Activating MET kinase rearrangements in melanoma and Spitz tumours. Nat Commun 2015, 6:7174

31. Puri N, Ahmed S, Janamanchi V, Tretiakova M, Zumba O, Krausz T, Jagadeeswaran R, Salgia R: c-Met is a potentially new therapeutic target for treatment of human melanoma. Clin Cancer Res 2007, 13: 2246-2253

32. Shain AH, Yeh I, Kovalyshyn I, Sriharan A, Talevich E, Gagnon A, Dummer R, North J, Pincus L, Ruben B, Rickaby W, D’Arrigo C, Robson A, Bastian BC: The genetic evolution of melanoma from precursor lesions. N Engl J Med 2015, 373:1926-1936

33. Li G, Schaider H, Satyamoorthy K, Hanakawa Y, Hashimoto K, Herlyn M: Downregulation of E-cadherin and Desmoglein 1 by autocrine hepatocyte growth factor during melanoma development. Oncogene 2001, 20:8125-8135

34. Natali PG, Nicotra MR, Di Renzo MF, Prat M, Bigotti A, Cavaliere R, Comoglio PM: Expression of the c-Met/HGF receptor in human melanocytic neoplasms: demonstration of the relationship to malignant melanoma tumour progression. Br J Cancer 1993, 68: 746-750

35. Zenali M, deKay J, Liu Z, Hamilton S, Zuo Z, Lu X, Bakkar R, Mills G, Broaddus R: Retrospective review of MET gene mutations. Oncoscience 2015, 2:533-541

36. Schmidt L, Duh FM, Chen F, Kishida T, Glenn G, Choyke P, Scherer SW, Zhuang Z, Lubensky I, Dean M, Allikmets R, Chidambaram A, Bergerheim UR, Feltis JT, Casadevall C, Zamarron A, Bernues M, Richard S, Lips CJ, Walther MM, Tsui LC, Geil L, Orcutt ML, Stackhouse T, Lipan J, Slife L, Brauch H, Decker J, Niehans G, Hughson MD, Moch H, Storkel S, Lerman MI, Linehan WM, Zbar B: Germline and somatic mutations in the tyrosine kinase domain of the MET proto-oncogene in papillary renal carcinomas. Nat Genet 1997, 16:68-73

37. Athauda G, Giubellino A, Coleman JA, Horak C, Steeg PS, Lee MJ, Trepel J, Wimberly J, Sun J, Coxon A, Burgess TL, Bottaro DP: cMet ectodomain shedding rate correlates with malignant potential. Clin Cancer Res 2006, 12:4154-4162

38. Ma PC, Tretiakova MS, MacKinnon AC, Ramnath N, Johnson C, Dietrich S, Seiwert T, Christensen JG, Jagadeeswaran R, Krausz T, Vokes EE, Husain AN, Salgia R: Expression and mutational analysis of MET in human solid cancers. Genes Chromosomes Cancer 2008, 47:1025-1037

39. Chattopadhyay C, Ellerhorst JA, Ekmekcioglu S, Greene VR, Davies MA, Grimm EA: Association of activated c-Met with NRASmutated human melanomas. Int J Cancer 2012, 131:E56-65

40. Gherardi E, Birchmeier W, Birchmeier C, Vande Woude G: Targeting MET in cancer: rationale and progress. Nat Rev Cancer 2012, 12: $89-103$

41. Lin S, Rusciano D, Lorenzoni P, Hartmann G, Birchmeier W, Giordano S, Comoglio P, Burger MM: C-met activation is necessary but not sufficient for liver colonization by B16 murine melanoma cells. Clin Exp Metastasis 1998, 16:253-265

42. Qian F, Engst S, Yamaguchi K, Yu P, Won KA, Mock L, Lou T, Tan J, Li C, Tam D, Lougheed J, Yakes FM, Bentzien F, Xu W, Zaks T, Wooster R, Greshock J, Joly AH: Inhibition of tumor cell growth, invasion, and metastasis by EXEL-2880 (XL880, GSK1363089), a novel inhibitor of HGF and VEGF receptor tyrosine kinases. Cancer Res 2009, 69:8009-8016

43. Christensen JG, Schreck R, Burrows J, Kuruganti P, Chan E, Le P, Chen J, Wang X, Ruslim L, Blake R, Lipson KE, Ramphal J, Do S, Cui JJ, Cherrington JM, Mendel DB: A selective small molecule inhibitor of c-Met kinase inhibits c-Met-dependent phenotypes in vitro and exhibits cytoreductive antitumor activity in vivo. Cancer Res 2003, 63:7345-7355

44. Surriga O, Rajasekhar VK, Ambrosini G, Dogan Y, Huang R, Schwartz GK: Crizotinib, a c-Met inhibitor, prevents metastasis in a metastatic uveal melanoma model. Mol Cancer Ther 2013, 12: $2817-2826$

45. Li FZ, Dhillon AS, Anderson RL, McArthur G, Ferrao PT: Phenotype switching in melanoma: implications for progression and therapy. Front Oncol 2015, 5:31

46. Alonso SR, Tracey L, Ortiz P, Perez-Gomez B, Palacios J, Pollan M, Linares J, Serrano S, Saez-Castillo AI, Sanchez L, Pajares R, Sanchez-Aguilera A, Artiga MJ, Piris MA, Rodriguez-Peralto JL: A highthroughput study in melanoma identifies epithelial-mesenchymal transition as a major determinant of metastasis. Cancer Res 2007, 67:3450-3460

47. Caramel J, Papadogeorgakis E, Hill L, Browne GJ, Richard G, Wierinckx A, Saldanha G, Osborne J, Hutchinson P, Tse G, Lachuer J, Puisieux A, Pringle JH, Ansieau S, Tulchinsky E: A switch in the expression of embryonic EMT-inducers drives the development of malignant melanoma. Cancer Cell 2013, 24:466-480

48. Koefinger P, Wels C, Joshi S, Damm S, Steinbauer E, BehamSchmid C, Frank S, Bergler H, Schaider H: The cadherin switch in melanoma instigated by HGF is mediated through epithelialmesenchymal transition regulators. Pigment Cell Melanoma Res 2011, 24:382-385

49. Grotegut S, von Schweinitz D, Christofori G, Lehembre F: Hepatocyte growth factor induces cell scattering through MAPK/Egr-1-mediated upregulation of Snail. EMBO J 2006, 25: $3534-3545$

50. Gaggioli C, Deckert M, Robert G, Abbe P, Batoz M, Ehrengruber MU, Ortonne JP, Ballotti R, Tartare-Deckert S: HGF induces fibronectin matrix synthesis in melanoma cells through MAP kinase-dependent signaling pathway and induction of Egr-1. Oncogene 2005, 24:1423-1433

51. Xu H, Tian Y, Yuan X, Wu H, Liu Q, Pestell RG, Wu K: The role of CD44 in epithelial-mesenchymal transition and cancer development. Onco Targets Ther 2015, 8:3783-3792

52. Recio JA, Merlino G: Hepatocyte growth factor/scatter factor induces feedback up-regulation of CD44v6 in melanoma cells through Egr-1. Cancer Res 2003, 63:1576-1582

53. Ilangumaran $\mathrm{S}$, Villalobos-Hernandez A, Bobbala D, Ramanathan S: The hepatocyte growth factor (HGF)-MET receptor tyrosine kinase signaling pathway: diverse roles in modulating immune cell functions. Cytokine 2016, 82:125-139

54. Finisguerra V, Di Conza G, Di Matteo M, Serneels J, Costa S, Thompson AA, Wauters E, Walmsley S, Prenen H, Granot Z, Casazza A, Mazzone M: MET is required for the recruitment of antitumoural neutrophils. Nature 2015, 522:349-353

55. Glodde N, Bald T, van den Boorn-Konijnenberg D, Nakamura K, O'Donnell JS, Szczepanski S, Brandes M, Eickhoff S, Das I, Shridhar N, Hinze D, Rogava M, van der Sluis TC, Ruotsalainen JJ, Gaffal E, Landsberg J, Ludwig KU, Wilhelm C, Riek-Burchardt M, Muller AJ, Gebhardt C, Scolyer RA, Long GV, Janzen V, Teng MWL, Kastenmuller W, Mazzone M, Smyth MJ, Tuting T, Holzel M: Reactive neutrophil responses dependent on the receptor 
tyrosine kinase c-MET limit cancer immunotherapy. Immunity 2017, 47:789-802.e9

56. Benkhoucha M, Molnarfi N, Kaya G, Belnoue E, Bjarnadottir K, Dietrich PY, Walker PR, Martinvalet D, Derouazi M, Lalive PH: Identification of a novel population of highly cytotoxic c-Metexpressing CD8(+) T lymphocytes. EMBO Rep 2017, 18:1545-1558

57. Trusolino L, Bertotti A, Comoglio PM: A signaling adapter function for alpha6beta4 integrin in the control of HGF-dependent invasive growth. Cell 2001, 107:643-654

58. McArthur GA, Chapman PB, Robert C, Larkin J, Haanen JB, Dummer R, Ribas A, Hogg D, Hamid O, Ascierto PA, Garbe C, Testori A, Maio M, Lorigan P, Lebbe C, Jouary T, Schadendorf D, O’Day SJ, Kirkwood JM, Eggermont AM, Dreno B, Sosman JA, Flaherty KT, Yin M, Caro I, Cheng S, Trunzer K, Hauschild A: Safety and efficacy of vemurafenib in BRAF(V600E) and BRAF(V600K) mutation-positive melanoma (BRIM-3): extended follow-up of a phase 3, randomised, open-label study. Lancet Oncol 2014, 15:323-332

59. Robert C, Karaszewska B, Schachter J, Rutkowski P, Mackiewicz A, Stroiakovski D, Lichinitser M, Dummer R, Grange F, Mortier L, Chiarion-Sileni V, Drucis K, Krajsova I, Hauschild A, Lorigan P, Wolter P, Long GV, Flaherty K, Nathan P, Ribas A, Martin AM, Sun P, Crist W, Legos J, Rubin SD, Little SM, Schadendorf D: Improved overall survival in melanoma with combined dabrafenib and trametinib. N Engl J Med 2015, 372:30-39

60. Hugo W, Shi H, Sun L, Piva M, Song C, Kong X, Moriceau G, Hong A, Dahlman KB, Johnson DB, Sosman JA, Ribas A, Lo RS: Non-genomic and immune evolution of melanoma acquiring MAPKi resistance. Cell 2015, 162:1271-1285

61. Wilson TR, Fridlyand J, Yan Y, Penuel E, Burton L, Chan E, Peng J, Lin E, Wang Y, Sosman J, Ribas A, Li J, Moffat J, Sutherlin DP, Koeppen H, Merchant M, Neve R, Settleman J: Widespread potential for growth-factor-driven resistance to anticancer kinase inhibitors. Nature 2012, 487:505-509

62. Krepler C, Xiao M, Sproesser K, Brafford PA, Shannan B, Beqiri M, Liu Q, Xu W, Garman B, Nathanson KL, Xu X, Karakousis GC, Mills GB, Lu Y, Ahmed TA, Poulikakos PI, Caponigro G, Boehm M, Peters M, Schuchter LM, Weeraratna AT, Herlyn M: Personalized preclinical trials in BRAF inhibitor-resistant patient-derived xenograft models identify second-line combination therapies. Clin Cancer Res 2016, 22:1592-1602

63. Straussman R, Morikawa T, Shee K, Barzily-Rokni M, Qian ZR, Du J, Davis A, Mongare MM, Gould J, Frederick DT, Cooper ZA, Chapman PB, Solit DB, Ribas A, Lo RS, Flaherty KT, Ogino S, Wargo JA, Golub TR: Tumour micro-environment elicits innate resistance to RAF inhibitors through HGF secretion. Nature 2012, 487:500-504

64. Qin Y, Roszik J, Chattopadhyay C, Hashimoto Y, Liu C, Cooper ZA, Wargo JA, Hwu P, Ekmekcioglu S, Grimm EA: Hypoxia-driven mechanism of vemurafenib resistance in melanoma. Mol Cancer Ther 2016, 15:2442-2454

65. Daud A, Kluger HM, Kurzrock R, Schimmoller F, Weitzman AL, Samuel TA, Moussa AH, Gordon MS, Shapiro GI: Phase II randomised discontinuation trial of the MET/VEGF receptor inhibitor cabozantinib in metastatic melanoma. Br J Cancer 2017, 116: 432-440

66. Cecchi F, Rabe DC, Bottaro DP: Targeting the HGF/MET signaling pathway in cancer therapy. Expert Opin Ther Targets 2012, 16:553-572

67. Patel M, Smyth E, Chapman PB, Wolchok JD, Schwartz GK, Abramson DH, Carvajal RD: Therapeutic implications of the emerging molecular biology of uveal melanoma. Clin Cancer Res 2011, 17:2087-2100

68. Puzanov I, Sosman J, Santoro A, Saif MW, Goff L, Dy GK, Zucali P, Means-Powell JA, Ma WW, Simonelli M, Martell R, Chai F, Lamar M, Savage RE, Schwartz B, Adjei AA: Phase 1 trial of tivantinib in combination with sorafenib in adult patients with advanced solid tumors. Invest New Drugs 2015, 33:159-168

69. Rimassa L, Assenat E, Peck-Radosavljevic M, Pracht M, Zagonel V, Mathurin P, Rota Caremoli E, Porta C, Daniele B, Bolondi L, Mazzaferro V, Harris W, Damjanov N, Pastorelli D, Reig M, Knox J, Negri F, Trojan J, López C, Personeni N, Decaens T, Dupuy M, Sieghart W, Abbadessa G, Schwartz B, Lamar M, Goldberg T, Shuster D, Santoro A, Bruix J: Tivantinib for second-line treatment of MET-high, advanced hepatocellular carcinoma (METIV-HCC): a final analysis of a phase 3, randomised, placebo-controlled study. Lancet Oncol 2018, 19:682-693 